\title{
The Prevalence of Clinically Significant Endoscopic Findings in Outpatients with Dyspepsia
}

\author{
LAMIAA A.A. EL-HABAB, M.Sc.; MOHAMED M. EL-BEDEWY, M.D.; MOHAMED A. TAWFIK, M.D. and \\ HANAA I. OKDA, M.D.
}

The Department of Internal Medicine, Faculty of Medicine, Tanta University

\begin{abstract}
Background: Dyspepsia is a common clinical problem. More patients with dyspepsia have no detectable lesion. Organic causes of dyspepsia only detected by endoscopy if suspected by age or alarm features.

Aim of Study: To evaluate the prevalence of significant endoscopic findings and use alarm features and the age in outpatients with dyspepsia in predicting the presence of Significant Endoscopic Findings (SEFS).

Patients and Methods: This is cross-sectional observational study was carried out in Tanta University Hospitals Internal Medicine Department on one hundred Egyptian outpatients with dyspepsia in the period from July 2017 to January 2018. All patients enrolled in this study were subjected to upper gastro intestinal endoscopy, and histopathological examination to suspected cases only.

Results: Our study showed that the prevalence of SEFS in dyspepsia patients was $25 \%$, mostly found in patients who were old age and or had alarm features. The most common endoscopic abnormality was non erosive gastritis $(73.2 \% \mathrm{n}$ $37)$, followed by small $\mathrm{HH}(70.9 \% \mathrm{n} 35)$, class A esophagitis represent $(16.8 \% \mathrm{n} 8)$, gastric ulcer disease was found in $(17 \%$ $\mathrm{n} 11)$, Malignancy was found in only $(6.4 \% \mathrm{n} 3)$, erosive esophagitis was found in $(6.4 \% \mathrm{n} 3)$, sever gastritis was found in $(12.8 \% \mathrm{n} 6)$ and sever doudonitis in $(4.3 \% \mathrm{n} 2)$.

Conclusion: The study showed the low prevalence of SEFs, and no need for endoscopy in young patients with no alarm features and they can be managed by non-endoscopic approach. However, it is highly recommended in all patients represented with alarming symptoms.
\end{abstract}

Key Words: Dyspepsia - Significant Endoscopic Findings (SEFS) - Alarming features.

\section{Introduction}

DYSPEPSIA is a poorly characterized syndrome thought to originate from anatomic or functional

Correspondence to: Dr. Lamiaa A.A. El-Habab,

The Department of Internal Medicine, Faculty of Medicine, Tanta University disorders of the upper Gastro-Intestinal Tract (GIT). It is a chronic, recurrent abdominal pain or discomfort in upper abdomen $[\mathbf{1 , 2}]$.

Dyspepsia mostly represented with symptoms of epigastric pain, burning, early satiety, bloating upper abdomen, fullness or nausea. And it is a wide spread disorder that affect $25-35 \%$ of the United States (US) population. It reflects most of population that seek health care and it has a huge economic cost to patient and health care system [3-5].

Functional dyspepsia according to Rome IV criteria is de find as symptoms for at least 3 months with onset at least 6 before one or more of the following criteria: Post fullness, early satiety, epigastric pain, epigastric burning and no evidence of structural disease that can explain the symptoms [6].

Symptoms of dyspepsia alone do not reliably identify individuals with malignancy or other important upper GIT pathology. So, patient age and alarm features have been used to categorize patient with dyspepsia who may harbor true pathology that may be found with endoscopy. So patient with new onset of dyspepsia after age of 55, those with symptoms and signs of dyspepsia and or presented with alarming symptoms as bleeding, weight loss, dysphagia and early satiety are advised to undergo initial endoscopy [7] as they called high risk patients with dyspepsia to exclude organic pathology as malignancy and peptic ulcer diseases. Large proportion of low risk patients with dyspepsia who are younger than 55 years of age and with no alarm symptoms to use a trial of PPI or H. pylori test prior to endoscopy [8] 
The prevalence of significant endoscopic finding using the broad definition of dyspepsia is $27.5 \%$ or $18 \%$ when using ROME criteria [9] and the endoscopic findings in patient with dyspepsia may be peptic ulcer (11\%), erosive esophagitis $(20 \%)$, malignancy, stricture or finding requiring no specific therapy [10]

\section{Patients and Methods}

This cross-sectional observational study carried out at Tanta University Hospitals in Internal Medicine Department in the period from July 2017 to January 2018. One hundred Egyptian outpatients with dyspepsia, of both sex and at least 18 years old with dyspepsia were included. Exclusion crieteria: Patients not fit for endoscopy as cardiac, chest or chronic kidney disease patient and patient of dyspepsia due to other disease as DM. An informed consent was taken from participant and the study was approved by Tanta Faculty of Medicine Ethical Committee.

\section{Data collection:}

All patients enrolled in this study were subjected to the following:

Complete history taking including age, special habit as smoking, drug history of $\mathrm{H} 2$ blocker, anticoagulant and anti platelets and history of alarm features as vomiting, weight loss, dysphagia, anemia, bleeding.

Clinical examination with special emphasis on gastrointestinal system.

The following laboratory investigations as $\mathrm{H}$. pylori antigen in stool and complete blood picture.

Upper gastro intestinal endoscopy, and histopathological examination to suspected legions.

\section{Statistical analysis [11,12]:}

Statistical presentation and analysis of the present study was conducted, using the mean, standard deviation and chi-square test by SPSS V.20. Chi-square: The hypothesis that the row and column variables are independent, without indicating strength or direction of the relationship. Pearson chi-square and likelihood-ratio chi-square. Fisher's exact test and Yates' corrected chi-square are computed for 2 X 2 tables, a $p$-value less than 0.05 was considered statistically significant.

\section{Results}

\section{Analysis of the results:}

Our study showed that the prevalence of Significant Endoscopic Findings (SEFS) in patients with dyspepsia was $25 \% \mathrm{n}=25$ and patients without SEFS were $75 \% \mathrm{n}=75$, in our study the mean age of patients with dyspepsia was $40.69 \pm 14.28$ years, of them 77 patients were younger than 55 years, of them 62 patients have no SEFs with ratio $(82.7 \%)$, on the other hand 23 patients were more than 55 years of them 13 patients have no SEFS with ratio $(17.3 \%)$ of all patient with no SEFS and 10 patients have SEFS with ratio $(40 \%)$ of all patient with SEFS so we found significant relation between SEFS and the age p-value (0.020). Patients who were less than 55 years old and have no alarm features were 44 patients, of them only 3 patients have SEFS $(6.8 \%)$ and patients who were less than 55 years old and have alarm features were 33 patients of them only 12 patients have SEFS $(36.4 \%)$ and patients who were $\geq 55$ and have no alarm features were 9 patients of them one patient have SEFS but patients who were $\geq 55$ and have alarm features were 14 patients of them 9 patient have SEFS (64.3\%), the presence or absence of alarm features was significantly associated with SEFs among the main age categories $<55, \geq 55$ with $p$-value (0.001 and 0.012) respectively as shown in (Table 1) and Figs. $(1,2)$, we have 64 patients were female of them 14 patients have SEFS (21.9\%) but 36 patients were males of them 11 patients have SEFS (30.6\%) so there was statistically non-significant association between sex and SEFS ( $p$-value 0.336), smokers were 14 and 7 of them have SEFS with ratio $(28 \%)$ ( $p$-value 0.020 ) as in (Table 2), Fig. (3), dyspepsia patient who were on NSAID were 21 and 10 of them had SEFS with ratio (40\%) and 11 patients had no SEFS $(14.7 \%)$ ( $p$-value 0.007) (Table 3), Fig. (4), $\mathrm{H}$. pylori status was positive and treated prior to endoscopy in 6 patients, negative in 54 patients, and positive and untreated prior to endoscopy in $40(40 \%)$ of patients and the ratio of SEFS in positive and negative patient was respectively $52 \%$, $48 \%$ ( $p$-value 0.181 ), as regard alarm features vomiting was reported in 26 patients of them 11 patients had SEFS (42\%) and 15 patients had no SEFS $(57.7 \%)$ ( $p$-value 0.716$)$, weight loss was reported in 11 patients of them 8 patients had SEFS (72\%) and 3 patients had no SEFS (27.3) ( $p$-value 0.033 ), anemia was reported in 18 patients of them 11 patients had SEFS $(61.1 \%)$ and 7 patients had no SEFS (38.9\%) ( $p$-value 0.074), Hematemesis and Melena ( $\mathrm{H} \& \mathrm{M})$ was reported in 4 patients of them 3 patients had SEFS (75.0\%) and 1 patient had no SEFS (25.0\%), patient with no H \& M were 43 of them 18 had SEFS (41.9\%) and 25 had no SEFS $(58.1 \%)$ so $\mathrm{H} \& \mathrm{M}$ as alarming features had no statistically significant association with SEFS ( $p$-value 0.227 ), Dysphagia was reported in 8 
patients of them 4 patients had SEFS (50\%) and 4 patient had no SEFS (50) ( $p$-value 0.740) among all patients 75 patients $(75 \%)$ had minor endoscopic abnormality, and only 25 patients $(25 \%)$ had significant endoscopic findings. These were more likely to be found in patients with alarm features compared to those without any alarm features $(84 \%$ versus $16 \% p$-value ${ }^{\left.0.001^{*}\right)}$, as in (Table 4$)$ and Fig. (5), as regard endoscopic findings gastric ulcer was reported in 11 patients 8 of them had alarm features $(17 \%)$, duodenal ulcer was present in 2 patients one of them had alarm features $(2.1 \%)$, reflux grade A was present in 8 patients 7 of them had alarm features $(14.9 \%)$, erosive esophagitis was present in 3 patients the 3 had alarm features $(6.4 \%)$, malignancy was present in 3 patients all of them had alarm features $(6.4 \%)$, one patients had gastric adenocarcinoma, one had GIST tumor, one had MALT lymphoma. Sever gastritis was reported in 6 patients all of them had alarm features $(12.8 \%)$, mild duodonitis was reported in 9 patients 6 of them had alarming features $(12.8 \%)$, sever duodinitis was reported in 2 patients all with alarming features and $\mathrm{HH}$ was reported in 35 patients 20 of them with alarming features $(42.6 \%)$.

Table (1): Significant endoscopic findings in patients with and without alarm features according to age.

\begin{tabular}{|c|c|c|c|c|}
\hline \multirow{2}{*}{ Age type } & \multicolumn{2}{|c|}{ Alarm features } & \multirow{2}{*}{ Total } & \multirow{2}{*}{$\begin{array}{c}p- \\
\text { value }\end{array}$} \\
\hline & No & Yes & & \\
\hline \multicolumn{5}{|l|}{$<55:$} \\
\hline \multicolumn{5}{|c|}{ Significant findings: } \\
\hline \multicolumn{5}{|c|}{ No: } \\
\hline $\mathrm{N}$ & 41 & 21 & 62 & $0.001 *$ \\
\hline$\%$ & $93.2 \%$ & $63.6 \%$ & $80.5 \%$ & \\
\hline \multicolumn{5}{|l|}{ Yes: } \\
\hline $\mathrm{N}$ & 3 & 12 & 15 & \\
\hline$\%$ & $6.8 \%$ & $36.4 \%$ & $19.5 \%$ & \\
\hline \multicolumn{5}{|l|}{ Total: } \\
\hline $\mathrm{N}$ & 44 & 33 & 77 & \\
\hline$\%$ & $\%$ & $100.0 \%$ & $100.0 \%$ & \\
\hline \multicolumn{5}{|l|}{ 55: } \\
\hline \multicolumn{5}{|c|}{ Significant findings: } \\
\hline \multicolumn{5}{|c|}{ No: } \\
\hline $\mathrm{N}$ & 8 & 5 & 13 & $0.012 *$ \\
\hline$\%$ & $88.9 \%$ & $35.7 \%$ & $56.5 \%$ & \\
\hline \multicolumn{5}{|l|}{ Yes: } \\
\hline $\mathrm{N}$ & 1 & 9 & 10 & \\
\hline$\%$ & $11.1 \%$ & $64.3 \%$ & $43.5 \%$ & \\
\hline \multicolumn{5}{|l|}{ Total: } \\
\hline $\mathrm{N}$ & 9 & 14 & 23 & \\
\hline$\%$ & $\%$ & $100.0 \%$ & $100.0 \%$ & \\
\hline
\end{tabular}

*: Significant $(p<0.05)$.

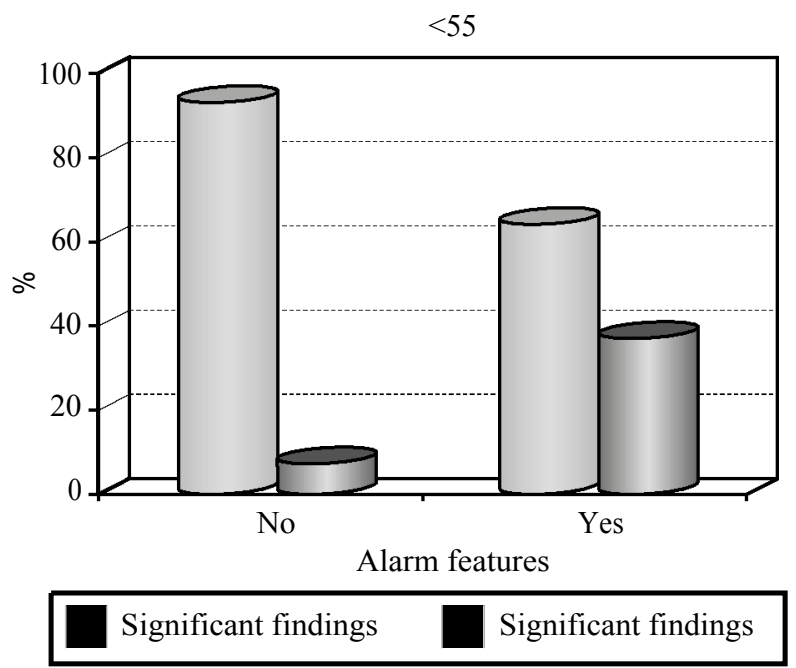

Fig. (1): Significant endoscopic findings in patients with and without alarm features according to age.

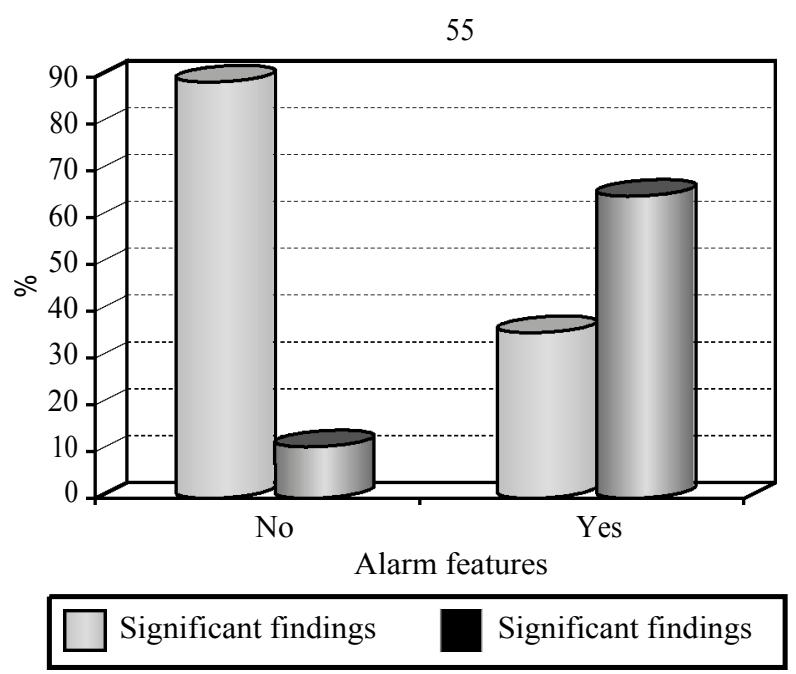

Fig. (2): Significant endoscopic findings in patients with and without alarm features according to age.

Table (2): Smoking characters in patients with dyspepsia and association with SEFS.

\begin{tabular}{|c|c|c|c|}
\hline Smoking & No & Yes & Total \\
\hline \multicolumn{4}{|l|}{ No: } \\
\hline $\mathrm{N}$ & 68 & 18 & 86 \\
\hline$\%$ & $90.7 \%$ & $72.0 \%$ & $86.0 \%$ \\
\hline \multicolumn{4}{|l|}{ Yes: } \\
\hline $\mathrm{N}$ & 7 & 7 & 14 \\
\hline$\%$ & $9.3 \%$ & $28.0 \%$ & $14.0 \%$ \\
\hline \multicolumn{4}{|l|}{ Total: } \\
\hline $\mathrm{N}$ & 75 & 25 & 100 \\
\hline$\%$ & $100.0 \%$ & $100.0 \%$ & $100.0 \%$ \\
\hline \multicolumn{4}{|c|}{ Chi-square: } \\
\hline $\begin{array}{l}\mathrm{x}^{2} \\
p \text {-value }\end{array}$ & \multicolumn{2}{|c|}{5.426} & \\
\hline
\end{tabular}

*: Significant $(p<0.05)$. 


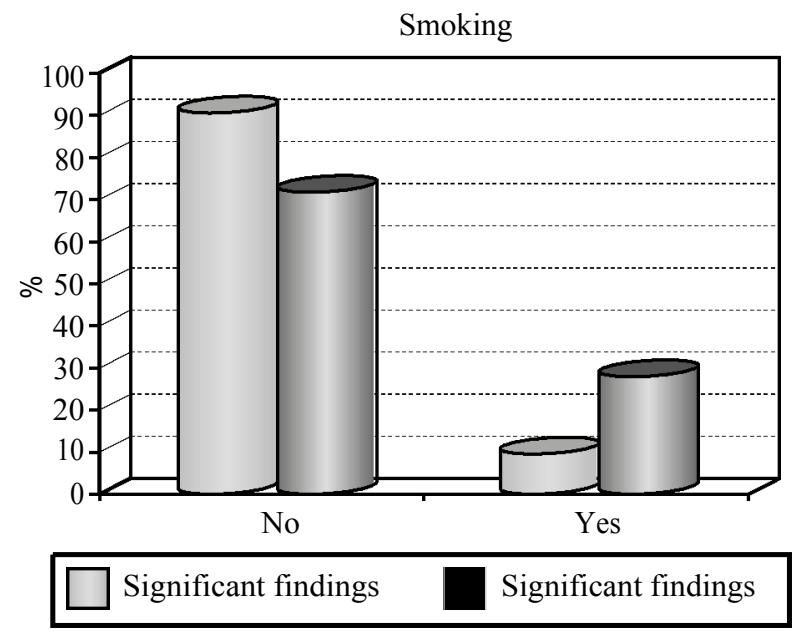

Fig. (3): Smoking characters in patients with dyspepsia and association with SEFS.

Table (3): Significant endoscopic findings in studied patients with and without nonsteroidal anti inflammatory drugs.

\begin{tabular}{|c|c|c|c|}
\hline \multirow{2}{*}{ NSAID } & \multicolumn{2}{|c|}{ Significant findings } & \multirow{2}{*}{ Total } \\
\hline & No & Yes & \\
\hline \multicolumn{4}{|l|}{ No: } \\
\hline $\mathrm{N}$ & 64 & 15 & 79 \\
\hline$\%$ & $85.3 \%$ & $60.0 \%$ & $79.0 \%$ \\
\hline \multicolumn{4}{|l|}{ Yes: } \\
\hline $\mathrm{N}$ & 11 & 10 & \\
\hline$\%$ & $14.7 \%$ & $40.0 \%$ & $21.0 \%$ \\
\hline \multicolumn{4}{|l|}{ Total: } \\
\hline $\mathrm{N}$ & 75 & 25 & 100 \\
\hline$\%$ & $100.0 \%$ & $100.0 \%$ & $100.0 \%$ \\
\hline \multicolumn{4}{|c|}{ Chi-square: } \\
\hline$x^{2}$ & \multicolumn{2}{|c|}{7.253} & \\
\hline$p$-value & \multicolumn{2}{|c|}{$0.007 *$} & \\
\hline
\end{tabular}

*: Significant $(p \leq 0.05)$.

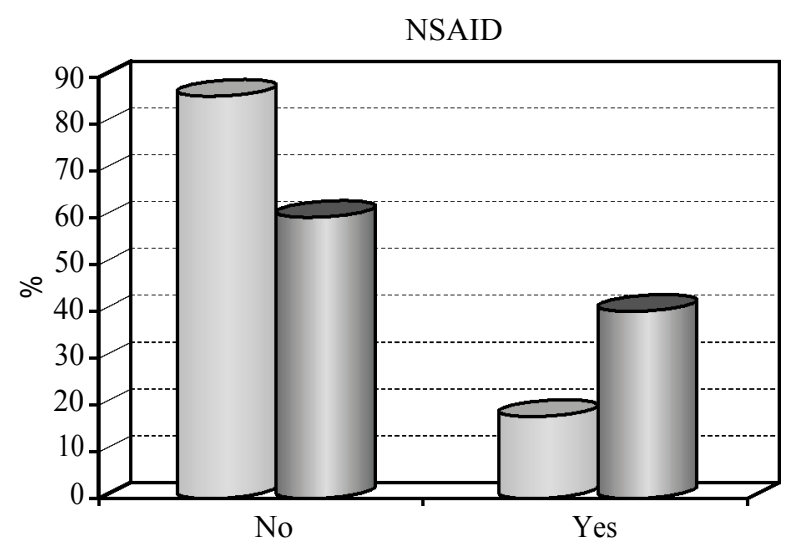

Significant findings

Significant findings

Fig. (4): Significant endoscopic findings in studied patients with and without nonsteroidal anti inflammatory drugs.
Table (4): SEFS in patient with and without alarm features.

\begin{tabular}{|c|c|c|c|}
\hline \multirow{2}{*}{$\begin{array}{l}\text { Alarm } \\
\text { features }\end{array}$} & \multicolumn{2}{|c|}{ Significant findings } & \multirow{2}{*}{ Total } \\
\hline & No & Yes & \\
\hline \multicolumn{4}{|l|}{ No: } \\
\hline $\mathrm{N}$ & 49 & 4 & 53 \\
\hline$\%$ & $65.3 \%$ & $16.0 \%$ & $53.0 \%$ \\
\hline \multicolumn{4}{|l|}{ Yes: } \\
\hline $\mathrm{N}$ & 26 & 21 & 47 \\
\hline$\%$ & $34.7 \%$ & $84.0 \%$ & $47.0 \%$ \\
\hline \multicolumn{4}{|l|}{ Total: } \\
\hline $\mathrm{N}$ & 75 & 25 & 100 \\
\hline$\%$ & $100.0 \%$ & $100.0 \%$ & $100.0 \%$ \\
\hline \multicolumn{4}{|c|}{ Chi-square: } \\
\hline $\begin{array}{l}x^{2} \\
p \text {-value }\end{array}$ & & & \\
\hline
\end{tabular}

*: Significant $(p<0.05)$.

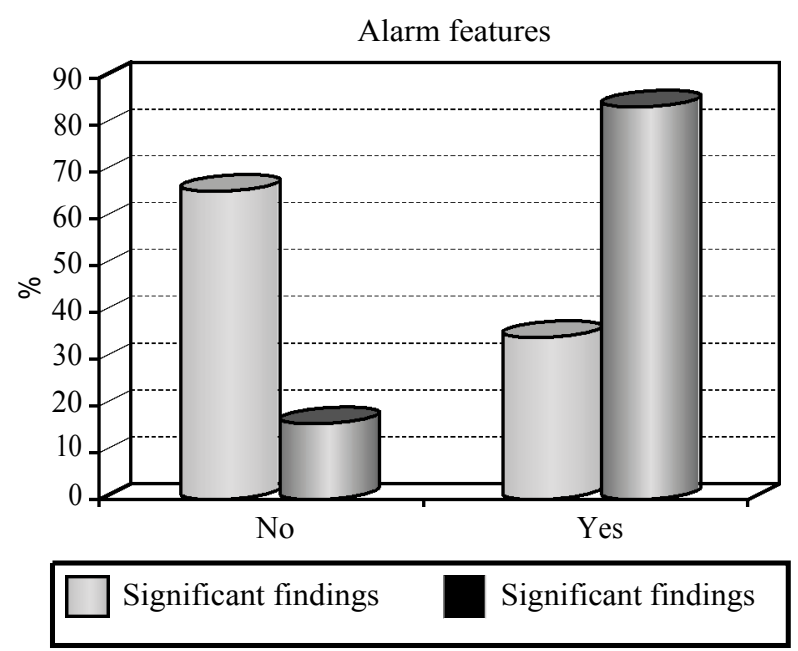

Fig. (5): SEFS in patient with and without alarm features.

\section{Discussion}

Dyspepsia is an important, common and demanding clinical problem. According to the international consensus meeting, dyspepsia is defined as pain or discomfort centered in the upper abdomen that is in or around the midline. It has been described as a negative sensation that can incorporate a wide variety of symptoms including bloating, early satiety, fullness, burning, nausea, continuous or intermittent vomiting [13-15]. This set of symptoms can be the manifestation of different organic,systemic or metabolic diseases (organic dyspepsia) or it may have no evident cause (functional dyspepsia). Thus, endoscopy of upper gastrointestinal tract is a safe and easily carried out procedure of high diagnostic value and also a therapeutic value in some cases [15]. In our study which conducted in Gastroenterology Outpatient Clinics and Endoscopy Unit at Tanta University Hospitals and 
included one hundred outpatients of dyspepsia of which some had alarm features and risk factors and others were free, the mean age of our study patients was $40.69 \pm 14.28$ years and this is in concordance with study by Khaled A et al., [16] in his study that assesed the prevalence of clinically significant endoscopic findings in outpatients of dyspepsia in which the mean age was 48.4 years \pm 12.6 years and this may lead to near results of both studies.

In the present study most patients were female $(64 \%)$ and (36\%) were males this opposite to study conducted by Ahmed G et al., [17] who studied the endoscopic evaluation of patients with dyspepsia in a secondary referral hospital in Egypt, male sex was predominant (51\%) but the result was low prevalence of SEFS as our study (35\%) and most population based studies showed that frequency of Uninvestigated Dyspepsia (UD) was not related to gender.

In the present study we found that there was a low prevalence of significant endoscopic findings $(25 \%)$ in outpatients with dyspepsia and the majority of these were found in patients with alarming features, significant endoscopic findings were found in patients with alarming features compared to those without any alarm features ( $84 \%$ versus $16 \% p$-value ${ }^{0.001 *)}$ and this is the same as the study conducted by Khaled A et al., [16] in his study that assessed the prevalence of clinically significant endoscopic findings in outpatients of dyspepsia, showed only $66(10.2 \%)$ patients had significant endoscopic findings mostly found in patients with alarming features compared to those without any alarm features ( $12.6 \%$ versus $5.4 \%$, $p$-value 0.004 ) and this the only study correlated between the presence of significant endoscopic findings and the presence of alarming features before our study and it showed the same result.

The present study show strong association between Non Steroidal Anti Inflammatory Drugs (NSAID) and Significant Endoscopic Findings (SEFS) ( $p$-value 0.007) and this also with the study conducted by Robin G et al., [18] who studied the clinical and endoscopic evaluation of dyspeptic patients attending a tertiary care hospital in South India and showed that NSAID consumption was reported in $31 \%$ of the studied patients and concluded that NSAID can provoke dyspepsia and it was a contributory factor. This also showed by A bdurahaman S. et al., [19] who studied the Uninvestigated Dyspepsia (UD) and associated factors of patients with gastrointestinal disorders in Dessie Referral Hospital, Northeast Ethiopia in this study he proved that NSAIDs use is statistically associated with UD ( $p$-value <0.001), however opposite to our study what conducted by Solomon OA et al., [20] who studied risk factors for un-investigated dyspepsia among primary care patients in northern Nigeria, showed that non significant association with NSAID and dyspepsia ( $p$-value 0.79 ).

Regarding smoking our study showed significant association with SEFS $p$-value 0.020) and this in concordance with Khaled A et al., [16] who showed a significant association between smoking and SEFS ( $p$-value 0.03), another study conducted by Ghosh D et al., [21] also proved that smoking had significant association with the development of reflux esophagitis, duodenal ulcer and gastric ulcer. On the other hand, Yasser Sh. et al., [22] found, that assessed the prevalence and risk factors of functional dyspepsia in a multi ethinic population in the United States and smoking not found to be a significant predictor of significant endoscopic finding ( $p$-value 0.1 ).

$\mathrm{H}$ pylori status in our study was non significant association with SEFS. We recorded the patients whose $\mathrm{H}$. pylori status was positive and were treated prior to endoscopy were $(6 \%)$, negative $(54 \%)$ of the patients, and positive untreated prior to endoscopy in (40\%) of patients and the ratio of SEFS in positive and negative patient was respectively $(52 \%, 48 \%)(p$-value 0.181$)$ and this in concordance with the study that conducted by Solomon OA et al., [20] and showed that H. pylori seropositivity was not related to the risk of developing dyspepsia. ( $p$-value $=0.10)$. But in disagreement of our results, other study by Abdurahaman S. et al., [19] who showed that $\mathrm{H}$. pylori infection was found to be significantly associated with UD ( $p$-value $<0.001)$ and in the study conducted by Robin $\mathrm{G}$ et al., [18]. The presence of H. pylori was significantly associated with endoscopic finding but it was more among alcoholics $(42 \%, p=0.036)$. So we found that the risk factors in our study, NSAIDS and smoking were more important in predicting SEFS than $\mathrm{H}$. pylori infection.

The endoscopic findings in our study were gastric ulcer disease that was found in 11 of patients $(17 \%)$, malignancy was found in only $3(6.4 \%)$ patients, all of whom had one or more alarming features. One patients had gastric adenocarcinoma, one had GIST tumor, one had MALT lymphoma that was associated with $\mathrm{H}$. pylori positive status and was advised to receive the treatment firstly. Erosive esophagitis was found in 3 patients (6.4\%), sever gastritis was found in 6 patient $(12.8 \%)$ and sever doudinitis in 2 patient (4.3\%), and this near 
to what shown in other study conducted by Ahmed $\mathrm{G}$ et al., [17] in which significant endoscopic findings were diagnosed in 487 (35\%). These included peptic ulcers in 245 patients (18\%), esophagitis in 191 (14\%), erosive gastro duodenitis in $112(8 \%)$ and UGI malignancy in $16(1 \%)$.

The prevalence of gastritis in Sahin et al., [23] who assessed the endoscopic findings of dyspeptic patient unresponsive to proton pump inhibitors. Northern Clinics of Istanbul in 446 patients was $48.4 \%, 16(3.6 \%)$ gastric ulcer, $36(8.1 \%)$ duodenal ulcer, $7(1.5 \%)$ duodonitis and $24(5.4 \%)$ esophagitis which is near our study.

Also in a study by Choomsri et al., [24] who studied the upper gastro intestinal endoscopy findings in patient presenting with dyspepsia, significant endoscopic lesions were found in $7 \%$ of the patients in the form of gastric ulcers, and only $1 \%$ was diagnosed to have gastric cancer, mainly primary gastro intestinal lymphoma which is a rare disease, but the stomach is the most frequent site of involvement for this neoplasm. The site of gastro intestinal lymphoma in all of the recent patients was the stomach.

\section{We Concluded that:}

- The problem of the evaluation and management of dyspepsia remain unresolved. Unfortunately, little data are available to guide physicians in the diagnosis and management of patients presenting with dyspepsia in the primary care setting.

- Because symptoms alone are not useful in distinguishing between causes. The patient's evaluation, including the medical history, physical examination and laboratory investigations are essential in the diagnosis.

- The physicians must decide when to treat empirically and when to refer the patient for endoscopy.

\section{Recommendations:}

\section{We recommend that:}

- As we found in our study the dyspepsia is a chronic and recurrent pain so the patient should deal with it as a chronic disease.

- Patient with age less than 55 years old and has no alarms features should be managed with symptomatic treatment as PPI, anti acid and prokinetics. We should not rush for endoscopy and we should re assure the patient that mostlythere is no organic pathology.

- But in patient with age more than 55 years old and or has alarms features should initially under go upper endoscopy.
Acknowledgements: We would like to thank all participants who helped during this study.

Conflict of interest: None declared.

\section{References}

1- HAMMER J.: "Identification of Individuals with Dyspepsia With a Simple, Minimally Invasive Test": A Single Center Cohort Study of the Oral Capsaicin Test, 113 (4): 584, 2018.

2- TAN V., LIU K., LAM F., et al.: "Rifaximin versus placebo for the treatment of functional dyspepsia". Randomised clinical trial, Alimentary pharmacology \& therapeutics, 45 (6): 767-76, 2017.

3- LI J., BIN R.B., JONE J., et al.: "Helicobacter pylori eradication therapy for": Systematic review and metaanalysis, World Journal of Gastroenterology, 22 (12): 3486, 2016.

4- BROOK R.A., KLEINMAN N.L., CHOUNG R.S., et al.: "Functional dyspepsia impacts absenteeism and direct and in direct costs,"Clinical Gastro enter ology and Hepatology, 8 (6): 498-503, 2010.

5- TACK J. and TALLEY N.J.: "Functional dyspepsiasymptoms, definitions and validity of the Rome III criteria," Nature Reviews Gastroenterology and Hepatology, 10 (3): 134-40, 2013.

6- TALLY N.J., NICHOLAS J. WALKER, et al.: (Nov.): "Functional dyspepsia current opinion in Gastro enterology, 32 (6): 467-73, 2016.

7- FORD A.C., MARWAHA A., LIM A., et al.: "Systematic review and meta-analysis of the prevalence of irritable bowel syndrome in individuals with dyspepsia". Clin. Gastroenterol. Hepatol., 8: 401-9, 2010.

8- FIORENZA J.P., TINIANOW A.M. and CHAN W.W.: "The initial management and endoscopic outcomes of dyspepsia in a low risk patient population," Digestive Diseases and Sciences, 61 (10): 2942-8, 2016.

9- FORD A.C., MARWAHA A., LIM A. and MOAYYEDI P.: "What is the prevalence of clinically significant endoscopic findings in subjects with dyspepsia? Systematic review and meta-analysis,"Clinical Gastroenterology and Hepatology, 8, (10): 830-7, 2010.

10- REJCHRT S., KOUPIL I., KOPÁCOVÁ M., et al.: "The prevalence and sociodemographic determinants of uninvestigated dyspepsia in the Czech Republic": A multicentre prospective study accomplished 10 years after the first study from the same geographical areas. European Journal of Gastroenterology \& Hepatology, 30 (1): 76-82, 2018.

11-VIDACOVIKE B.: 'International statistical review to line intersect sampling. In: Encyclopedia of statistical scis science.by KTZ S, Balakrishnan N, read B, et al., ${ }^{2 n d}$ Ed. CH 6th. Hobken NJ.: Wiely interscience: P: 262-332, 2006.

12- VERMA J.: "Statistics computer programe. In: Asample guide in IBM SpSS statistics for Version 20,0 By: Kirkpatirick A and Feeny C, student Ed. 4 th. Belmont, Calif: Wads Worth, cengage learning, P80-100, 2013.

13- CHIBA N.:" Definitions of Dyspepsia": Time for a Reappraisal. Eur. J. Surgery, 164 (Supp 583): 14-23, 1998. 
14- SANJIV M. and KHEAN-LEE G.: "Epidemiology of functional dyspepsia "A global perspective. World $\mathbf{J}$. Gastroenterol., 12 (17): 2661-6, 2006.

15- BIELSA-M.V., AGUILERA-C.J., MANRIQUE M.A., et al.: "Guías clinicas de diagnóstico y tratamiento de la dyspepsia. Epidemiología, definición, clasificación". Rev. Gastroenterol. Mex., 72: 286-7, 2007.

16- KHALED A. ANTONIOS W. and EMAD Q.: "Low Prevalence of Clinically Significant Endoscopic Findings in Outpatients with Dyspepsia" Gastroenterology Research and Practice ID3543681, 2017.

17- AHMED G., BASEL E., AIDA A., ANTHONY AXON, et al.: "Endoscopic evaluation of patients with dyspepsia in a secondary referral hospital in Egypt" Alexandria Journal of Medicine, 51-179-184, 2015.

18- ROBIN G. and THOMAS A. :"Clinical and endoscopic evaluation of dyspeptic patients attending a tertiary care hospital in South India: A prospective study" Asian Journal Of Medical Sciences, 8 (1): 58-63, 2016.

19- ABDURAHAMAN S., ZEMENU and WONDMAGEG D.: "Uninvestigated dyspepsia and associated factors of patients with gastrointestinal disorders in Dessie Referra Hospital, Northeast Ethiopia". Gastroenterology, 10: 0170723, 2018.

20- SOLOMON O. and AJAYI A.: "Risk factors for uninvestigated dyspepsia among primary care patients in northern Nigeria" African Health Sciences, Vol. 13 Issue 4, 2013.

21- GHOSH D., BARUA U. and SAHA S.: "Endoscopic evaluation of dyspeptic patients" Bangladesh Med. J., 42 (3), 2013.

22- YASSER SH. and HESHAM B.: "The prevalence and risk factors of functional dyspepsia in a multi thenic population in the united states" American J. of Gasteroenterology, 99: 2210-6, 2014

23- SAHIN M., AKBULUT C., DOLAPCIOGLU C., et al.:" Endoscopic finding of dyspeptic patient unresponsive to proton pump inhibitors". North Clin. Istanbul., 1: 15865, 2014.

24- CHOOMSRI P., BUMPENBOON W., WASUTHIT Y., et al.:" Upper gastro intestinal Endoscopy Findings inpatient presenting with Dyspepsi a. Thai. J. Surg., 31: 7-12, 2010 


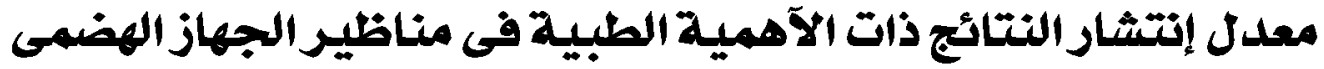

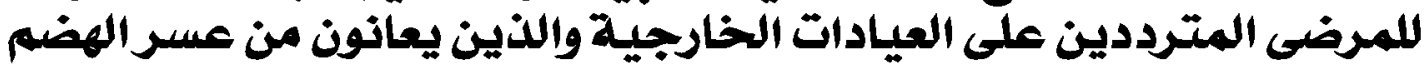

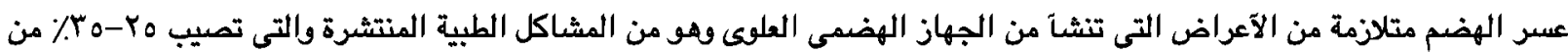

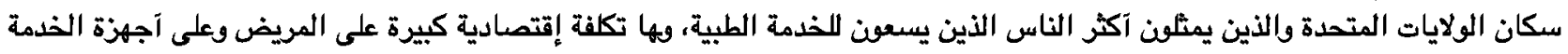

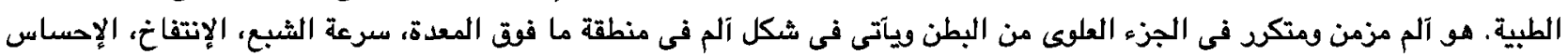

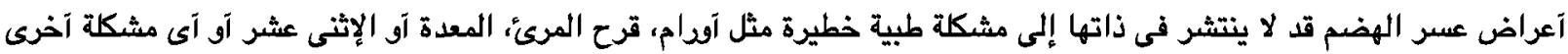

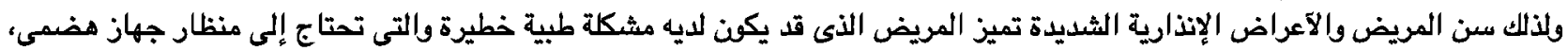

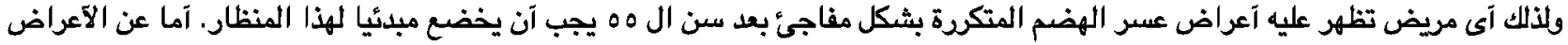

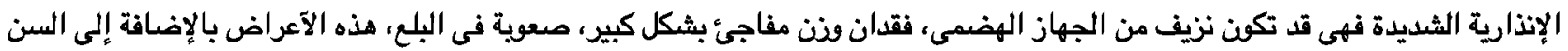

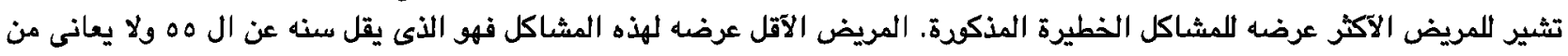
الآعراض الخطيرة آو لم يسبق له تناول آى علاج مبدئى لميكرب المعدة آو الآدوية التى تقلل من إفراز حامض المض المعدة.

الهدف من البحث: دراسة نسبة إنتشار النتائج ذات الآهمية الطبية فى مرضى العيادات الخارجية والذين يعانون من عسر الهضم وإستخدام

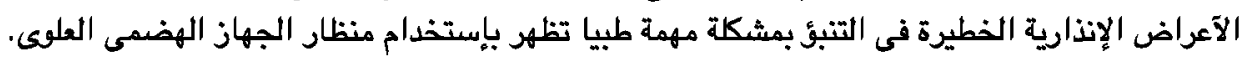

البحت: آجريت الدراسة على مائة من المرضى البالغين الذين يعانون من عسر هضم فى العيادات الخارجية فى مستشفيات جامعة طنطا.

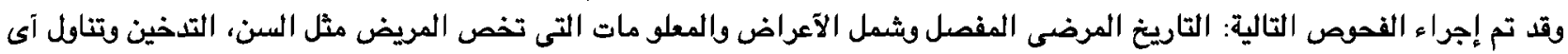
آدوية للمعدة التى تقلل إفراز حامض المعدة آو مضادات التجلط.

فحص إكلينيكى كامل، عمل تحليل الميكروب الحلزونى للمعدة عن طريق البراز، عمل صودة دم كاملة. وقد تم عمل منظار جهاز مضمى علوى لكل الحالات.

النتائج: غالية الحالات التى كانت تعانى من عسر الهضم لم تظهر لها نتائج مهمة طبيا وإن النتائج ذات الآهمية الطبية كانت آكثر ظهورا

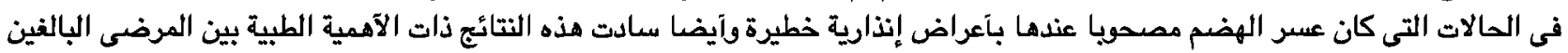
من العمر أكثر من خمسة وخمسون عاما مقارنة بالآعمار الصغيرة.

التوصيات: منظار الجهاز الهضمى العلوى مهم جدا في تثخيص حالات عسر الهضم المزمنة ولكنه ليس بالضرودة آن يكون آول خطوة

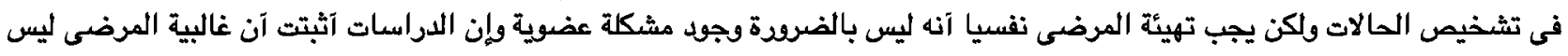
لايهم مشكلة.

ولكن: منظار الجهاز الهضمى الطلوى يجب آن يكون بالضرورة آول خطوة فى تثخيص المرضى الذين يعانون من عسر الهضم ولايهم آعراض إنذارية خطيرة وسنهم أكبر من خمسة وخمسون عاما. 